\section{A Synthetic Retinoid Am80 (Tamibarotene) Rescues the Memory Deficit Caused by Scopolamine in a Passive Avoidance Paradigm}

\author{
Koichi SHUdo, ${ }^{a}$ Hiroyuki KagEChIKA, ${ }^{a}$ \\ Noriyuki YAMAZAKI, ${ }^{b}$ Masaharu IGARASHI, ${ }^{b}$ and \\ Chiaki TATEDA $^{b}$ \\ ${ }^{a}$ Research Foundation Itsuu Laboratory; 2-28-10 Tamagawa, \\ Setagaya-ku, Tokyo 158-0094, Japan: and ${ }^{b}$ New Drug Development \\ Research Center, Inc.; 452-1 Toiso, Eniwa, Hokkaido 061-1405, \\ Japan. \\ Received July 30, 2004; accepted September 6, 2004
}

Memory deficit in rats treated with scopolamine was rescued by several synthetic retinoids, RAR-ligands (Am80, Am555S, Tp80) and an RXR-ligand (HX630). These results may have implications for the treatment of Alzheimer's disease, agerelated dementia, Parkinson's disease, and other neurological disorders.

Key words retinoid; Alzheimer's disease; tamibarotene; dementia; RAR-ligand

It is well established that retinoic acid induces undifferentiated cells to differentiate into more mature cells ${ }^{1)}$; an early observation was the differentiation of promyelocytic HL60 cells to neutrophils. ${ }^{2,3)}$ Differentiation to neurons and glia has also been observed consistently with various strains of embryonic carcinoma and teratocarcinoma cells, and also with stem cells and neuroblastoma cells. ${ }^{4)}$ Retinoid signaling plays a key role in the development of the central nervous systems. ${ }^{5}$

Many genes have now been shown to be regulated directly or indirectly, by retinoic acid or retinoids at the transcriptional level during differentiation and neuron outgrowth, including genes encoding transcription factors, cell surface receptors, neuropeptides and growth factors. ${ }^{6}$ Alzheimer's disease is also suggested to involve a defect of retinoid signaling. ${ }^{7)}$ An important observation is that null mutation of retinoic acid receptors RAR- $\beta$ and RXR- $\gamma$ results in a decline of hippocampal long-term potentiation and long-term depression, ${ }^{8)}$ implying that retinoic acid is required for memory and learning tasks. Nevertheless, pharmacological interest in retinoids is still limited.

There are number of synthetic retinoids, each of which has characteristic pharmacology ${ }^{9)}$ : i.e., there are differences in specificity for retinoic acid receptor RAR- $\alpha,-\beta$ and $-\gamma$ subtypes, specificity for retinoic acid X receptor RXR- $\alpha$, $-\beta$ and $-\gamma$ subtypes, binding to cellular retinoic acid binding protein, agonist/antagonist activity, potency, absorption, metabolism, and toxicity (some retinoids are severely irritating or allergenic). Furthermore, the interactions of holoreceptors with co-regulators are also highly characteristic, depending on cells and tissues, and even subtle differences of cellular environment. Thus, we need to screen compounds carefully to select drug candidates for the treatment of neurological disorders such as Alzheimer's and Parkinson's diseases, and in vivo animal experiments are essential for this purpose.

* To whom correspondence should be addressed. e-mail: kshudo@itsuu.or.jp
For the screening of compounds to treat memory deficits, including age-related and Alzheimer's disease-related amnesia or dementia, the passive avoidance test using a shuttle box is simple and efficient. In this method, amnesia is induced with scopolamine, as a model of the main clinical symptom of Alzheimer's disease; cholinergic agents reverse this effect in both rodents and human beings. On the other hand, benzodiazepine-receptor agonists have been shown to produce anterograde amnesia. It is of great interest to know whether the scopolamine-induced memory deficit is rescued by compounds other than neurotransmitters and related compounds. Here, we show that several synthetic retinoids can overcome the memory deficit induced by scopolamine in rats.

\section{MATERIALS AND METHODS}

Compounds Am80 (tamibarotene) ${ }^{3)} \mathrm{Am} 555 \mathrm{~S},{ }^{10)} \mathrm{Tp} 80,{ }^{11)}$ and $\mathrm{HX} 630^{12}$ were prepared as described and were used as suspensions in $0.5 \%$ methyl cellulose solution. Scopolamine was purchased from Sigma.

Animals Slc:Wister male rats, 6 weeks of age, were purchased from Japan SLC. Their body weights were 231$248 \mathrm{~g}$.

Passive Avoidance Test The test was performed according to the step-through method described by Jarvik and Kopp. ${ }^{13)}$ The apparatus consists of a two-compartment acrylic box with a lighted compartment connected to a darkened box with shutter door. Rats, as soon as they entered the dark compartment, received a punishing electrical shock $(1.5 \mathrm{~mA}, 3 \mathrm{~s})$. The latency period before entering the dark compartment was measured. The latency period was measured each day ( $24 \mathrm{~h}$ interval) for several successive days. For memory disruption, animals were injected with the amnesic agent, scopolamine $(0.5 \mathrm{mg}$ or $0.25 \mathrm{mg} / \mathrm{kg}$, s.c.) $30 \mathrm{~min}$ before the avoidance trial. The latency periods were measured up to a maximum of $300 \mathrm{~s}$. The test compound was administered p.o., $3 \mathrm{~h}$ before the scopolamine injection. All results shown in the figures are given as the mean \pm S.E. The significance of differences between the scopolamine group (without retinoid) and the retinoid-administered groups was evaluated by Mann-Whitney's $U$-test.

\section{RESULTS}

The memory deficit-inducing effect of scopolamine $(0.5 \mathrm{mg} / \mathrm{kg}$ or $0.25 \mathrm{mg} / \mathrm{kg}$, i.v. $)$ was potent: the increase of

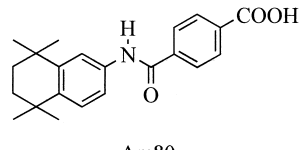

Am80

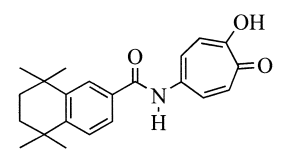

Tp80
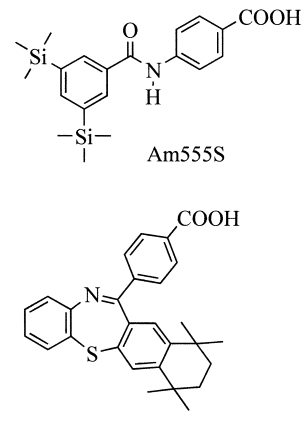

HX630 


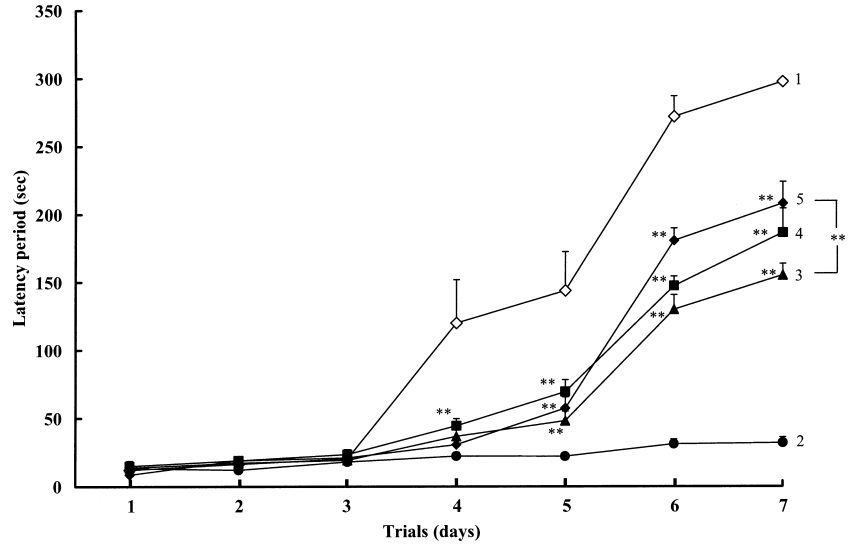

Fig. 1a. Effect of Am80 on the Memory Deficit Caused by Scopolamine in a Passive Avoidance Paradigm in Rats

Each value with vertical bar represents the mean \pm S.E. of 8 rats. $* * p<0.01$, significantly different from control (curve 2 ) by Mann-Whitney's $U$-test. $\quad * *$ shows the significance between the two at the seventh day. 1: $-\diamond-$ blank, 2: $-\square-$ scopolamine $0.5 \mathrm{mg} / \mathrm{kg} / \mathrm{d}, 3:-\boldsymbol{\Delta}-\mathrm{Am} 805 \mathrm{mg} / \mathrm{kg} / \mathrm{d}$ (scopolamine $0.5 \mathrm{mg} / \mathrm{kg} / \mathrm{d}$ ), 4: 一 - Am80 $10 \mathrm{mg} / \mathrm{kg} / \mathrm{d}$ (scopolamine $0.5 \mathrm{mg} / \mathrm{kg} / \mathrm{d}$ ), 5: —-Am80 $15 \mathrm{mg} / \mathrm{kg} / \mathrm{d}$ (scopolamine $0.5 \mathrm{mg} / \mathrm{kg} / \mathrm{d})$

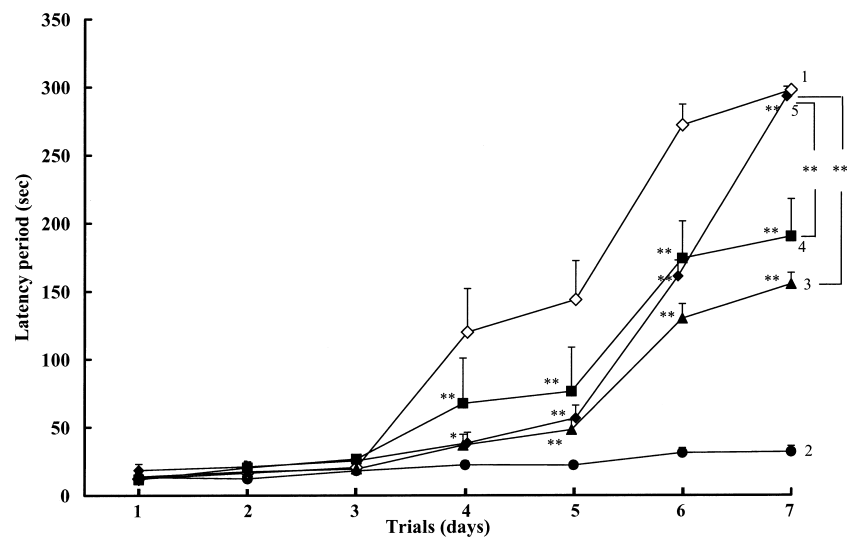

Fig. 1b. Effect of Am80 and HX-630 on the Memory Deficit Caused by Scopolamine in a Passive Avoidance Paradigm in Rats

Each value with vertical bar represents the mean \pm S.E. of 8 rats. $* * p<0.01$, significantly different from control (curve 2) by Mann-Whitney's $U$-test. $\quad * *$ shows the significance between the two at the seventh day. $1:-\diamond-$ blank, $2:-\bigcirc-$ scopolamine $0.5 \mathrm{mg} / \mathrm{kg} / \mathrm{d}, 3:-\boldsymbol{\Delta}$ - Am80 $5 \mathrm{mg} / \mathrm{kg} / \mathrm{d}$ (scopolamine $0.5 \mathrm{mg} / \mathrm{kg} / \mathrm{d}$ ), $4:-\square-H X-630$ $20 \mathrm{mg} / \mathrm{kg} / \mathrm{d}$ (scopolamine $0.5 \mathrm{mg} / \mathrm{kg} / \mathrm{d}$ ), $5: \quad \longrightarrow-A m 80 \quad 5 \mathrm{mg} / \mathrm{kg} / \mathrm{d}+\mathrm{HX}-630$ $20 \mathrm{mg} / \mathrm{kg} / \mathrm{d}$ (scopolamine $0.5 \mathrm{mg} / \mathrm{kg} / \mathrm{d}$ ).

latency in rats administered scopolamine was far slower than that in the normal rats (curves 1, 2, Fig. 1a). The control (blank) rats reached the maximum measured latency period (300s) after 5-7 trials, while the latency of the scopolamine-treated rats at this point was only about $50 \mathrm{~s}$. The deficit caused by scopolamine was dose-dependently overcome by the administration of the synthetic retinoid Am80 (tamibarotene, $5,10,15 \mathrm{mg} / \mathrm{kg}$ ) at $3 \mathrm{~h}$ prior to the administration of scopolamine (curves 3, 4, 5, Fig. 1a). At the effective doses of Am80 no significant change in locomotive activity or general pharmacology was observed. ${ }^{14)}$ At a lower dose of scopolamine, the effect of Am80 was more evident (curves 4, 5, Fig. 2a), supporting the view that the effect of Am80 is not due to any toxicity. Other retinoids, Am555S (30 mg/ $\mathrm{kg}$ ) and Tp80 $(30 \mathrm{mg} / \mathrm{kg}$ ) were also active in the same assay (date not shown). The potencies paralleled the ability to transactivate RAR- $\alpha$ and RAR- $\beta$, and the differentiating activity towards

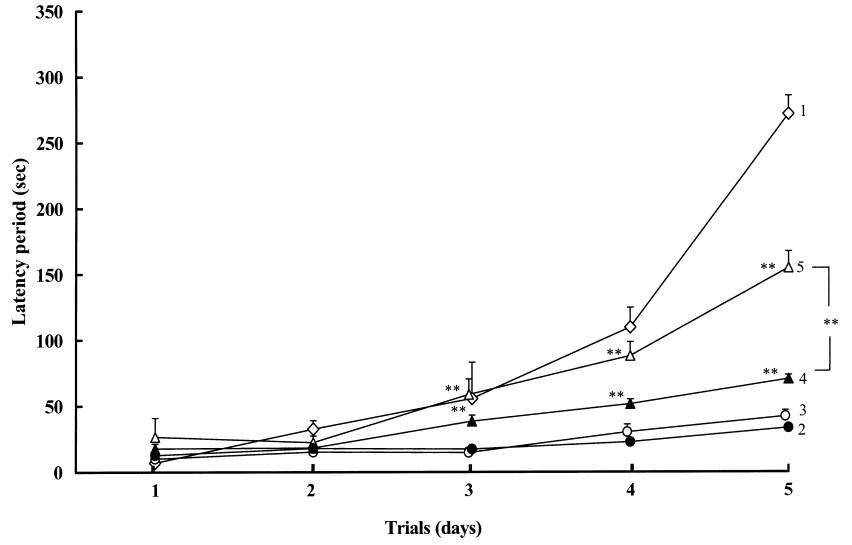

Fig. 2a. Effect of Am80 on the Memory Deficit Caused by Scopolamine in a Passive Avoidance Paradigm in Rats

Each value with vertical bar represents the mean \pm S.E. of 6 or 8 rats. $* * p<0.01$, significantly different from control (curve 2 ) by Mann-Whitney's $U$-test. $* *$ shows the significance between the two at the fifth day. $1:-\diamond-$ blank, 2 : -- scopolamine $0.5 \mathrm{mg} / \mathrm{kg} / \mathrm{d}, 3:-\bigcirc$ - scopolamine $0.25 \mathrm{mg} / \mathrm{kg} / \mathrm{d}, 4:-\boldsymbol{\Delta}$ - Am80 $5 \mathrm{mg} / \mathrm{kg} / \mathrm{d}$ (scopolamine $0.5 \mathrm{mg} / \mathrm{kg} / \mathrm{d}$ ), 5 : $-\triangle-A m 805 \mathrm{mg} / \mathrm{kg} / \mathrm{d}$ (scopolamine $0.25 \mathrm{mg} / \mathrm{kg} / \mathrm{d}$ ).

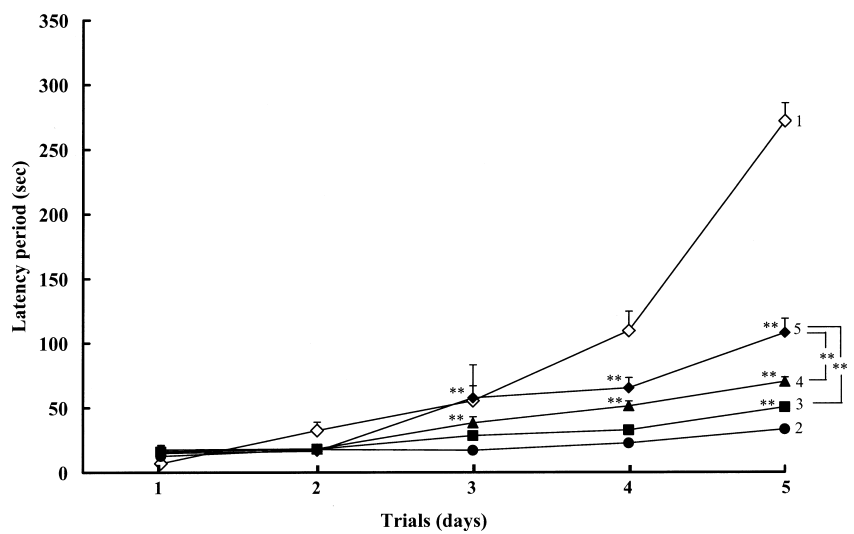

Fig. 2b. Effect of Am80 and HX-630 on the Memory Deficit Caused by Scopolamine in a Passive Avoidance Paradigm in Rats

Each value with vertical bar represents the mean \pm S.E. of 6 or 8 rats. $* * p<0.01$, significantly different from control (curve 2 ) by Mann-Whitney's $U$-test. $\quad * *$ shows the significance between the two at the fifth day. $1:-\diamond-$ blank, $2:-0-$ scopolamine $0.5 \mathrm{mg} / \mathrm{kg} / \mathrm{d}, 3:-\boldsymbol{\Delta}$ - Am80 $5 \mathrm{mg} / \mathrm{kg} / \mathrm{d}$ (scopolamine $0.5 \mathrm{mg} / \mathrm{kg} / \mathrm{d}$ ), 4: ———HX-630 $10 \mathrm{mg} / \mathrm{kg} / \mathrm{d}$ (scopolamine $0.5 \mathrm{mg} / \mathrm{kg} / \mathrm{d}$ ), $5: \longrightarrow$ Am $80 \quad 5 \mathrm{mg} / \mathrm{kg} / \mathrm{d}+\mathrm{HX}-630$ $10 \mathrm{mg} / \mathrm{kg} / \mathrm{d}$ (scopolamine $0.5 \mathrm{mg} / \mathrm{kg} / \mathrm{d}$ ).

HL60 cells, and elongation of the latency period by these compounds was almost equal to that by Am80 $(10 \mathrm{mg} / \mathrm{kg})$. Another kind of retinoid, the RXR ligand HX630 $(20 \mathrm{mg} / \mathrm{kg}$, Fig. $1 \mathrm{~b}$ curve $4 ; 10 \mathrm{mg} / \mathrm{kg}$, Fig. $2 \mathrm{~b}$, curve 3 ), also reduced the deficit caused by scopolamine (Figs. 1b, 2b), and the combined effect of HX630 and Am80 was marked.

\section{DISCUSSION}

It is surprising that retinoids are able to reverse scopolamine-induced memory deficit. Scopolamine is anticholinergic, but it seems unlikely that the retinoid molecules act as agonists or antagonists from chemical structural considerations. Nevertheless, the effects of the retinoids are potent and dose-dependent, with no apparent indication of toxicity. As already noted retinoic acid/RAR (and/or RXR) pathways play multiple biological roles, and the underlying mechanism 
of the effect observed here may be associated with the retinoidal actions of the compounds. Molecular-level experimental studies are needed, but several possible mechanisms can be considered.

1. Retinoid enhances the expression of the dopamine receptor $\mathrm{D} 2 \mathrm{R}$, since the $\mathrm{D} 2 \mathrm{R}$ gene has an upstream promoter sequence that can be activated by the RAR-RXR family. ${ }^{15}$ ) Enhanced transcription of D2R may sensitize the neural cells to dopamine, perhaps leading to long-term potentiation. This would be consistent with the observation that dopa is effective against scopolamine-induced amnesia. ${ }^{16)}$ If this hypothesis is correct, Am80 and other retinoids may be beneficial in the treatment of Parkinson's disease too.

2. NMDA receptors may be regulated by retinoids. This is supported by the observation that functional NR1/NR2Btype NMDA receptors are expressed in neuroblastoma cells differentiated in vitro by retinoid. ${ }^{17)}$ If this is the case, a novel pathway including glutamate, NMDA and cholinergic agents may be involved in learning and memory.

3 . The serotoninergic system has been implicated in learning and memory, ${ }^{18)}$ and 5HT1A-receptor antagonists produced a dose-dependent amnesic effect. However, genes which encode serotonine-related receptor proteins are not thought to be regulated by retinoids. ${ }^{\text {) }}$

4. Synthesis of proteins such as $\mathrm{NGF}^{19)} \mathrm{BMP}^{20)}$ and other growth factors such as interleukins ${ }^{21)}$ may play a role. These growth factors are influenced by retinoid receptors, including RXR receptors. In particular, nerve growth factor inducible gene (NGFI-B or Nur77) ${ }^{22)}$ is known to dimerize with RXR, whose ligands include 9-cis-retinoic acid and HX630.

5. Participation of amyloid can not be ruled out, since the expression level of amyloid precursor protein is regulated by retinoid. ${ }^{23)}$

Other mechanisms might also be possible, and would presumably include a molecular event at the transcriptional level.

The RXR ligand HX630 also restored the scopolamineinduced memory deficit, and enhanced the effect of Am80. Sometimes RXR ligands can dramatically enhance the transcriptional activity of nuclear receptor ligands. ${ }^{12)}$ However, it is noteworthy that HX630 alone could restore the memory deficit, suggesting that another pathway in addition to the RAR/RXR pathway takes part in the process. If the activity is based on RAR receptors, it is at least clear that participation of RAR $-\gamma$ is not required for the reversal of the memory deficit by retinoids, because Am 80 is RAR- $\alpha$ and RAR- $\beta$ selective and, hardly binds to RAR- $\gamma$. It may be important to consider receptor selectivity if retinoids are to be used therapeutically. Although the pharmacological and molecular mechanisms of the observed effect remain to be established, we believe the present observations raise interesting questions in neuroscience, and may provide a hint for the treatment of some neurological disorders.

\section{REFERENCES}

1) Sporn M. B., Roberts A., Goodman D. S., "The Retinoids," Vol. 1, 2, Academic Press, London, 1984.

2) Collins S. J., Gallo R. C., Gallagher R. E., Nature (London), 270, 347-349 (1977).

3) Kagechika H., Kawachi E., Hashimoto Y., Shudo K., Chem. Pharm. Bull., 32, 4209-4212 (1984).

4) Maden M., Nature Rev. Neurosci., 3, 843-853 (2002).

5) McCaffery P. J., Adams J., Maden M., Rosa-Molinar E., Eur. J. Neurosci., 18, 457-472 (2003).

6) Balmer J. E., Blomhoff R., J. Lipid Res., 43, 1773-1808 (2002).

7) Goodman A. B., Pardee A. B., Proc. Natl. Acad. Sci. U.S.A., 100, 2901-2905 (2003).

8) Chiang M.-Y., Misner D., Kempermann G., Schikorski T., Giguere V., Sucov H. M., Gage F. H., Stevens C. F., Evans R. M., Neuron, 21, 1353-1361 (1998).

9) Nau H., Blanar W. S. (ed.), "Retinoid. The biochemical and molecular basis of vitamin A and related retinoid action (Handbook of experimental pharmacology. Vol. 139)," Springer-Verlag, Heidelberg, 1999.

10) Yamakawa T., Kagechika H., Kawachi E., Hashimoto Y., Shudo K., J. Med. Chem., 33, 1430-1437 (1990).

11) Ebisawa M., Ohta K., Kawachi E., Fukasawa H., Hashimoto Y., Kagechika H., Chem. Pharm. Bull., 49, 501-503 (2001).

12) Umemiya H., Fukasawa H., Ebisawa M., Eyrolles L., Kawachi E., Eisenmann G., Gronenmeyer H., Hashimoto Y., Shudo K., Kagechika H., J. Med. Chem., 40, 4222-4234 (1997).

13) Jarvik M. E., Kopp R., Psychol. Rep., 21, 221-224 (1967).

14) Yamazaki N., unpublished results.

15) Algate D. R., Atterson P. R., Beard D. J., Doteuchi M., Jobling C. M., Munt P. L., Oyo Yakuri/Pharmacometrics, 47, 451-463 (1994).

16) Sanad T. S., Krezel W., Chambon P., Borrelli E., Proc. Natl. Acad. Sci. U.S.A., 94, 14349-14354 (1997).

17) Pizzi M., Boroni F., Bianchetti A., Moraitis C., Sarnico I., Banarese M., Goffi F., Valerio A., Spano P., Eur. J. Neurosci., 16, 2342-2350 (2002).

18) Meneses A., Hong E., Prog. Neurophychopharmacol. Biol. Phychiatry, 21, 273-296 (1997).

19) Kinameri E., Matsuoka I., Mol. Brain Res., 117, $221-227$ (2003).

20) Calza L., Giuliani A., Fernandes M., Pirondi S., D’Intino G., Aloe L., Gialdino L., Proc. Natl. Acad. Sci. U.S.A., 100, 7325-7330 (2003).

21) Kagechika H., Kawachi E., Fukasawa H., Saito G., Iwanami N., Umemiya H., Hashimoto Y., Shudo K., Biochem. Biophys. Res. Commun., 231, 243-248 (1997).

22) Milbranet J., Neuron, 1, 183-188 (1988).

23) Adlerz L., Beckman M., Holback S., Tehranian R., Cortes T. V., Ivedrfeldt K., Mol. Brain Res., 119, 62-72 (2003). 